\title{
Hypogonadotropic Hypogonadism in a Homozygous MC4R Mutation Carrier and the Effect of Sibutramine Treatment on Body Weight and Obesity- Related Health Risks
}

\author{
Irena Aldhoon Hainerováa Hana Zamrazilováb Dana Sedláčkováb Vojtěch Hainer ${ }^{b}$ \\ ${ }^{a}$ Department of Paediatrics and Centre for Research of Diabetes, Metabolism and Nutrition, Third Faculty of Medicine, Charles University, \\ ${ }^{b}$ Obesity Management Centre, Institute of Endocrinology, Prague, Czech Republic
}

\section{Keywords}

Monogenic obesity - MC4R · Hypogonatropic hypogonadism - Sibutramine treatment

\section{Summary}

Objective: The first aim of our study was to define the hypogonadism manifested by low testosterone levels and incomplete male secondary sex characteristics in a 20-year-old male homozygous MC4R mutation carrier (G181D). The second aim of our study was to evaluate the effect of the anti-obesity drug sibutramine in this patient who failed to respond to an intensive lifestyle intervention and exhibited continuous weight gain. Case Report: Anthropometric, biochemical, hormonal and psycho-behavioural parameters were investigated both at baseline and after a 1-year sibutramine treatment. To characterise the hypogonadism, sex steroid profile, concentrations of luteinizing hormone and follicle-stimulating hormone were determined. Standard tests with gonadotropin-releasing hormone, thyrotropin-releasing hormone and human chorionic gonadotropin were conducted. Brain magnetic resonance imaging was performed to exclude organic hypothalamic-pituitary lesions. Clinical examination and endocrine investigations revealed hypogonadotropic hypogonadism. Sibutramine induced body weight maintenance as well as improvement in body composition and obesity-related metabolic abnormalities. Conclusion: We described the first case of hypogonadotropic hypogonadism in a MC4R homozygous mutation carrier. The potential association between the hormonal disturbance and the hypothalamic derangement caused by the MC4R mutation should be considered. In addition, we demonstrated that sibutramine treatment had a favourable effect on body weight maintenance and obesity-related health risks.

\section{Introduction}

Hypogonadotropic hypogonadism (HH) is one of the phenotypic features of subjects carrying mutations of several genes located within the leptin-melanocortin signalling pathway. These genes include the leptin gene ( $L E P)$, the leptin receptor gene $(L E P R)$ and the prohormone convertase 1 gene $(P C 1)[1,2]$. HH has not so far been reported in melanocortin 4 receptor gene $(M C 4 R)$ mutation carriers [2].

Homozygous mutation carriers of $M C 4 R$ suffer from early onset morbid obesity and its complications. They often present with hyperphagia and binge eating [2], though binge eating was not confirmed in a subsequent study [3]. To date, no specific effective therapy for these patients has been found. Some studies have shown that an intensive lifestyle intervention in MC4R mutation carriers leads to a similar weight loss as in non-carriers $[4,5]$. However, in a study by Reinehr et al. [5], 16 children harbouring heterozygous $M C 4 R$ mutations of reduced receptor function had greater difficulties achieving weight maintenance in comparison to non-carriers. A recently published case report of an adolescent with complete $M C 4 R$ deficiency (due to compound heterozygosity) demonstrated a poor weight loss even after gastric banding [6]. A report by Aslan et al. [7] however indicated that Roux-en- $\mathrm{Y}$ gastric

\section{KARGER}

Fax +497614520714

Information@Karger.de

www.karger.com (c) 2011 S. Karger GmbH, Freiburg

$1662-4025 / 11 / 0044-0324 \$ 38.00 / 0$

Accessible online at:

www.karger.com/ofa
Irena Aldhoon Hainerová, M.D., Ph.D.

Department of Paediatrics and Centre for Research of Diabetes, Metabolism and Nutrition Third Faculty of Medicine, Charles University

Šrobárova 50, 10034 Prague 10, Czech Republic

Tel. +420 2-67162561, Fax-72736326

ihainer@hotmail.com 
Fig. 1. Weight development of homozygous $M C 4 R$ mutation carrier since his birth and body weight maintenance when treated by sibutramine.

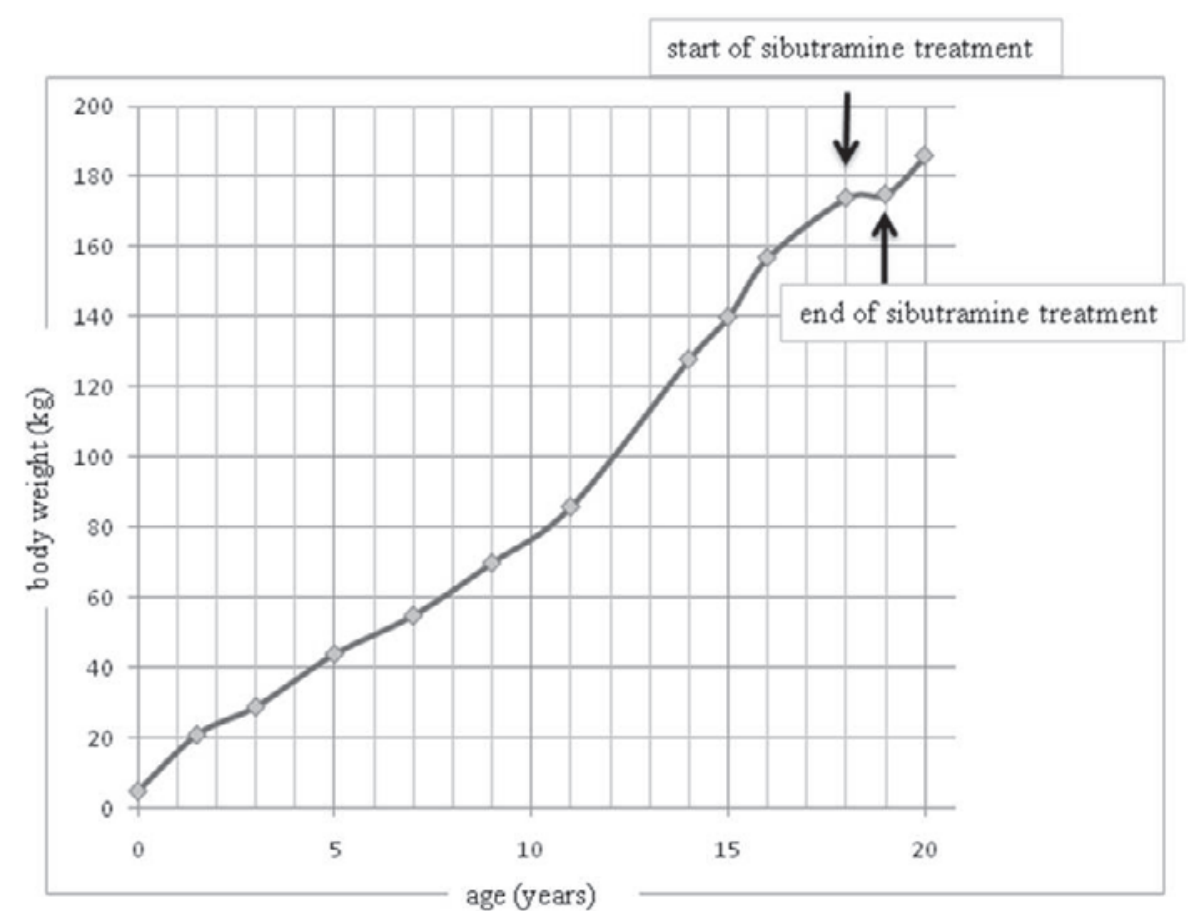

bypass seems to be more efficient for heterozygous functionally significant $M C 4 R$ mutation carriers.

The effect of sibutramine as a centrally acting serotoninnorepinephrine re-uptake inhibitor has previously been evaluated in children with hypothalamic obesity [8]. It was shown that the sibutramine-induced weight loss in subjects with hypothalamic obesity, including 2 patients with unspecified $M C 4 R$ mutations, was less pronounced than that in subjects with common obesities [8].

\section{Case Report}

In 2004, a homozygous loss-of-function mutation G181D in $M C 4 R$ was identified in a 14-year-old boy with weight of $130.0 \mathrm{~kg}$ (z-score 6.9), height of $171 \mathrm{~cm}$ (z-score 0.4) and BMI of $44.5 \mathrm{~kg} / \mathrm{m}^{2}$ (z-score 8.6) [4]. The patient suffered from morbid obesity since his early childhood (fig. 1) accompanied by a loss of control over food intake. He demonstrated a high score on the Eating Inventory (hunger 7 and disinhibition 8) [9] and replied positively to all questions in binge eating syndrome questionnaires [10]. Insulin resistance, biochemical and ultrasound signs of fatty liver, increased levels of uric acid and triglycerides and decreased levels of HDL-cholesterol were all observed over time. He has been treated for hypertension with losartan ( $25 \mathrm{mg} /$ day) since 2008.

Repeated testing revealed lower levels of serum testosterone (5.64, $2.77,4.15,9.66,8.31 \mathrm{nmol} / \mathrm{l}$; normal range 10.0-34.0 nmol/l) and dihydrotestosterone (DHT) $(0.72,0.8 \mathrm{nmol} / \mathrm{l}$; normal range $0.9-3.6 \mathrm{nmol} / \mathrm{l})$. The patient's testicular volume was 19 and $20 \mathrm{ml}$, and the length of the flaccid penis was approximately $7 \mathrm{~cm}$. He presented with spare and female-like pubic hair (Tanner stage for pubic hair - PH3) and was lacking axillary, facial and chest hair (fig. 2). He has never shaved. Our patient did not report any problems concerning libido or erection.

At the age of 19 years, low levels of luteinizing hormone (LH; 2.4 $\mathrm{IU} / \mathrm{l})$, follicle-stimulating hormone (FSH; $1.6 \mathrm{IU} / \mathrm{l})$ and testosterone
(2.77 nmol/l) were confirmed. Over a 2-year follow-up period, oestradiol fluctuated from normal $(0,265 \mathrm{nmol} / \mathrm{l})$ to slightly elevated $(0,323$ $\mathrm{nmol} / \mathrm{l})$ levels. Serum free thyroxine, thyroid-stimulating hormone (TSH), prolactin (PRL), cortisol, adrenocorticotropic hormone and insulin-like growth factor-1 were repeatedly within the normal range. Levels of sex hormone-binding globulin (SHBG) were repeatedly low (8.6, $10.3,11.8 \mathrm{nmol} / \mathrm{l}$; normal range $23.0-50.4 \mathrm{nmol} / \mathrm{l})$. Lower levels of dehydroepiandrosterone $(5.3,11.27 \mathrm{nmol} / \mathrm{l}$; normal range $11.6-38.7 \mathrm{nmol} / \mathrm{l})$ and dehydroepiandrosterone sulfate $(6.15,4.06 \mathrm{umol} / \mathrm{l}$; normal range 7.2-16.1 umol/l) were also detected. The androstendione level was within the normal range.

In January 2010, a standard gonadotropin-releasing hormone (GnRH) stimulation test with a 100- $\mu$ g dose of GnRH (LHRH Ferring; Ferring Arzneimittel GmbH, Kiel, Germany) and a thyrotropin-releasing hormone (TRH) stimulation test with 200- $\mu \mathrm{g}$ dose of TRH (TRH Ferring; Ferring Arzneimittel $\mathrm{GmbH}$ ) were undertaken. The baseline and peak serum LH, FSH, TSH and PRL responses are shown in table 1.

In response to $\mathrm{GnRH}$ administration, a moderate increase of $\mathrm{LH}$ (approximately 3 times the baseline value) was observed. This increase of the LH level in 180 min was accompanied by a slight elevation of serum testosterone. There was a physiological response of both TSH and PRL levels to the TRH administration.

A human chorionic gonadotropin (HCG) stimulation test was performed with a daily dose of 1,500 IU of HCG (Pregnyl; Organon Laboratories Ltd., Cambridge, UK) administered for 3 days. The HCG stimulation led to a slight increase of serum testosterone (from 2.77 to 9.66 $\mathrm{nmol} / \mathrm{l}$ ) and DHT (from 0.72 to $2.03 \mathrm{nmol} / \mathrm{l}$ ) levels.

A hyperinsulinaemic euglycaemic clamp with insulin in a dose of 40 and $80 \mathrm{mIU} / \mathrm{min} / \mathrm{m}^{2}$ was also undertaken. Glucose disposal rates were $1.6 \mathrm{mg} / \mathrm{kg} / \mathrm{min}$ with $40 \mathrm{mIU} / \mathrm{min} / \mathrm{min}^{2}$ of insulin and $2.5 \mathrm{mg} / \mathrm{kg} / \mathrm{min}$ when $80 \mathrm{mIU} / \mathrm{min} / \mathrm{m}^{2}$ was applied. These results confirmed severe insulin resistance. Our patient exhibited no clinical or laboratory signs of growth hormone and ACTH deficiency (data not shown).

In order to evaluate the morphology of the patient's pituitary gland and hypothalamus, brain magnetic resonance imaging (MRI) was performed. The hypothalamic-pituitary region was shown to have normal structure. 
Fig. 2. $M C 4 R$ mutation carrier at the age of 19 years (weight $175.8 \mathrm{~kg}$, height 178 $\mathrm{cm}$, BMI $55.5 \mathrm{~kg} / \mathrm{m}^{2}$ ). Notice the absence of chest hair.

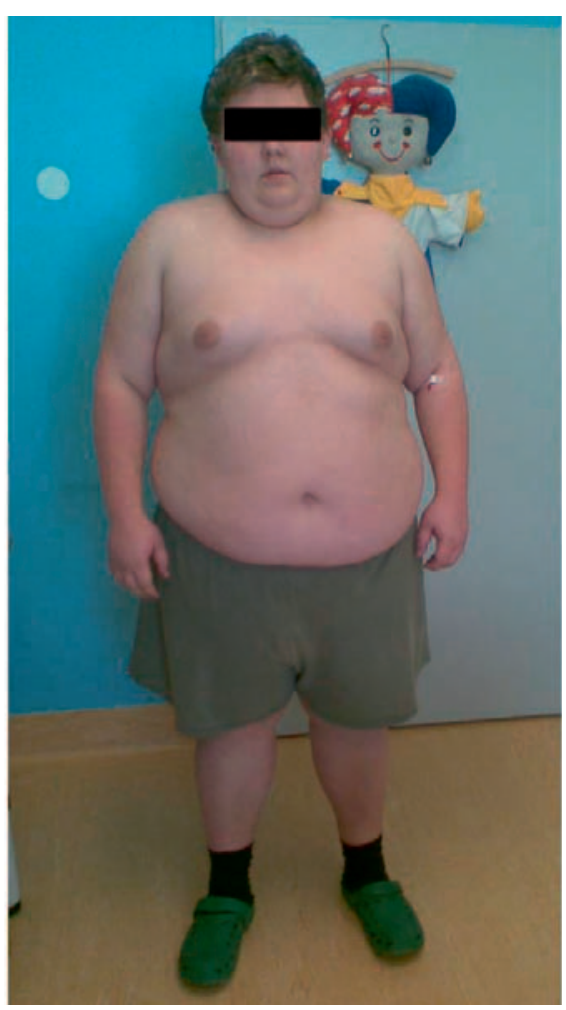

Due to the fact that the patient failed to respond to an intensive lifestyle intervention and exhibited continuous weight gain (approximately $20 \mathrm{~kg} /$ year $)$, the anti-obesity drug sibutramine $(10 \mathrm{mg} /$ day $)$ was administered in 2008 for 12 months. Under the sibutramine treatment, body weight maintenance was achieved (weight $174.4 \rightarrow 175.8 \mathrm{~kg}$, BMI $55 \rightarrow$ $55.5 \mathrm{~kg} / \mathrm{m}^{2}$ ) (fig. 1). Body composition assessed by dual X-ray densitometry Lunar iDXA ${ }^{\mathrm{TM}}$ (GE Medical Systems Lunar, Madison, WI, USA) was improved (body fat percent: $55.6 \rightarrow 53.8 \%$, fat mass: $97.0 \rightarrow 94.6 \mathrm{~kg}$ ). In addition, improvements in metabolic parameters were also demonstrated (table 2). Decreases in the hunger score $(7 \rightarrow 1)$ and disinhibition score $(8 \rightarrow 4)$ of the Eating Inventory as well as in the Beck depression score $(5 \rightarrow 3)$ were observed. Sibutramine was well tolerated by this patient and was not accompanied by an increase either of blood pressure (controlled by losartan treatment) or of pulse rate. One year after cessation of the anti-obesity drug, body weight increased by $10.8 \mathrm{~kg}$ to $186.6 \mathrm{~kg}$ (fig. 1). Both the fasting insulin level $(23.5 \rightarrow 80.2 \mathrm{mIU} / \mathrm{l})$ and insulin resistance HOMA-index $(5.1 \rightarrow 19.2)$ increased as well as the activity of liver enzymes. Serum leptin concentrations corresponded to enlarged fat stores $(58.9 \mathrm{ng} / \mathrm{ml})$. Elevated fasting levels of neuropeptide Y (NPY) (112.9 pmol/l; normal range 30.8-69.3 pmol/l) were also recorded.

\section{Discussion}

This is the first case of a $M C 4 R$ mutation carrier presenting with $\mathrm{HH}$. Within the leptin-melanocortin pathway, $\mathrm{HH}$ is
Table 1. Results of GnRH and TRH stimulation tests ${ }^{\mathrm{a}}$

\begin{tabular}{lccccc}
\hline Hormones (reference ranges) & $0 \mathrm{~min}$ & $20 \mathrm{~min}$ & $60 \mathrm{~min}$ & $120 \mathrm{~min}$ & $180 \mathrm{~min}$ \\
\hline LH, IU/l (0.5-10.0) & 1.8 & 6.3 & 6.6 & 4.8 & 4.7 \\
FSH, IU/l (2.0-10.0) & 1.4 & 1.8 & 2.0 & 1.9 & 1.8 \\
Testosterone, nmol/l (10.0-34.0) & 4.15 & - & - & 5.57 & 7.78 \\
TSH, mIU/l (0,270-4.2) & 2.32 & 13.13 & - & 3.47 & - \\
PRL, ng/ml (4.1-15.3) & 15.7 & 39.2 & 24.5 & 16.5 & 12.3 \\
\hline
\end{tabular}

$\mathrm{FSH}=$ follicle-stimulating hormone; $\mathrm{GnRH}=$ Gonadotropin-releasing hormone; $\mathrm{LH}=$ luteinizing hormone; $\mathrm{PRL}=$ prolactin $; \mathrm{TRH}=$ thyrotropin-releasing hormone; $\mathrm{TSH}=$ thyroid-stimulating hormone.

${ }^{a}$ To convert testosterone from $\mathrm{nmol} / \mathrm{l}$ to $\mu \mathrm{g} / \mathrm{l}$, divide by 3.46. LH and FSH were determined on Stratec automatic analyzer from Immunotech (Marseilles, France) by immunoradiometric assay (Immunotech, Prague, Czech Republic). TSH and PRL were measured on the Cobas 6000 analyzer (ROCHE Diagnostics GmbH, Mannheim, Germany) using the sandwich electrochemiluminescent immunoassay. Testosterone was determined by standard radioimmunoassay.
Table 2. Body weight and metabolic parameters before and after the sibutramine treatment and 1 year after the antiobesity drug withdrawal $^{\mathrm{a}}$

\begin{tabular}{lccc}
\hline & Before treatment & After treatment & 1 year after treatment \\
\hline Body weight, $\mathrm{kg}$ & 174.4 & 175.8 & 186.6 \\
Triglyceride, mmol/l (0.01-2.26) & 2.32 & 1.96 & 1.6 \\
Total cholesterol/HDL-cholesterol ratio & 5.7 & 4.7 & 4.5 \\
HOMA-index & 8.1 & 5.1 & 19.2 \\
Insulin, mIU/l (2.6-24.9) & 33.5 & 23.5 & 80.2 \\
Uric acid, $\mu$ mol/l $(202.3-416.5)$ & 588 & 518 & 437 \\
ALT, $\mu$ kat/l $(<0.83)$ & 1.38 & 0.89 & 1.65 \\
AST, $\mu$ kat/l $(<0.85)$ & 0.89 & 0.63 & 0.92 \\
GMT, $\mu$ kat/l $(0.17-1.19)$ & 1.19 & 0.77 & 1.16 \\
\hline
\end{tabular}

ALT = alanine transaminase; AST = aspartate aminotransferase; GMT = glutamyl transferase; HDL = high-density lipoprotein; HOMA = homeostatic model assessment.

${ }^{\mathrm{a}}$ Reference ranges of hormones are in brackets. 
found in subjects with mutations of $L E P, L E P R$ and $P C 1$ $[1,11,12]$. The $\mathrm{HH}$ in $L E P$ and $L E P R$ mutation carriers is due to the defect in leptin signalling which has been shown to be an important hormone for the onset of puberty [13]. The leptin level in our patient corresponded to enlarged body fat stores. The mechanism of $\mathrm{HH}$ in $\mathrm{PC1}$ mutation carriers has however not yet been elucidated. The impaired processing of the respective pro-hormones necessary for the onset of puberty has been discussed as one possibility [12].

There is evidence that the melanocortin pathway is involved in sex function regulation [14]. Van der Ploeg et al. [15] recently reported that an administration of MC4R agonists augments erections and improve erection dysfunction. However, in another study [16] intracerebroventricular administration of an MC4R antagonist delayed the onset of male sexual behaviour. Recent experimental studies [17] demonstrated that acetylated melanocortin peptides in the brain might mediate the regulation of reproductive function by leptin. The exact role of melanocortins in human sexual maturity therefore remains unknown.

In our patient, low levels of testosterone, DHT, LH and FSH were found. According to Arver et al. [18], total testosterone levels of less than $8 \mathrm{nmol} / \mathrm{l}$ highly support a diagnosis of hypogonadism. As DHT plays an important role in the development of secondary sex characteristics and acts as the primary androgen in the hair follicle, its decreased levels could contribute to the phenotype characteristics found in our patient. It is known that severe obesity in men may be associated with delayed puberty and/or hypogonadism. This may be due to low levels of SHBG [19] and of total and free testosterone coupled with high levels of oestrogens (oestradiol, oestrone) [20]. This hormonal abnormality results from high activity of aromatase in the enlarged fat stores [19]. Aromatase is an enzyme which catalyses the conversion of androgens (testosterone, androstendione) into oestrogens (oestradiol and oestrone). Constantly decreased levels of SHBG and intermittently increased levels of oestradiol might have affected the sex development in our patient as well. The fact that the patient did not report any sexual dysfunction must be evaluated carefully due to its subjective evaluation and the age of the patient.

It has been previously described that LH levels in severely obese patients are inappropriately low; therefore hypothalamic and pituitary function appears to be suppressed [21]. It seems that high serum oestrogens levels exert an inhibitory effect on pituitary LH secretion which then results in $\mathrm{HH}$ [21]. Hayes et al. [22] concluded that oestrogens also reduce hypothalamic GnRH-pulse frequency. Vermeulen et al. [23] reported that low levels of testosterone in obese men are the consequence of impaired hypothalamic-pituitary function which leads to decreased LH pulse amplitude. In our patient, the gonadotropin levels were much lower than those observed in men with severe common obesities. This supports the idea of a primarily hypothalamic origin of the hypogonadism and a causal relationship to the $M C 4 R$ mutation. Results of endocrine investigations in previous patients with $L E P$ and $L E P R$ mutations have pointed to a defect in hypothalamic activation of the pituitary axis $[1,11]$.

HCG administration in our patient induced only a slight increase in serum testosterone levels. This lower stimulation may be due to diminished HCG absorption from adipose tissue than would be seen from muscle tissue in any lean subject. Further, the testosterone response to short-term administration of HCG may also be blunted because Leydig cell steroidogenic enzymes are down-regulated. Results of both stimulation tests ( $\mathrm{GnRH}, \mathrm{HCG})$ and normal brain MRI provide additional support for the hypothalamic disturbance of GnRH secretion in this patient.

$\mathrm{HH}$ has not so far been described in other MC4R mutation carriers. To date, less than 20 homozygous carriers in 10 different $M C 4 R$ mutations have been identified [4, 24, 25, 26, 27]. Only one homozygous $M C 4 R$ mutation carrier (40-yearold woman) with complete loss of function and normal gonadotropin levels was described [25]. Other published homozygous cases had either not reached puberty or the mutations led to partial activity, which may influence the phenotype of the affected individuals [24, 26]. In a few cases, no age of the homozygous $M C 4 R$ mutation carrier was presented [26], or the gonadotropin levels were not determined [27].

Homozygous MC4R mutation carriers suffer from severe obesity with increased mass (not only fat mass but also lean body mass), increased linear growth, hyperphagia and severe hyperinsulinaemia [2,4]. Observed elevated fasting levels of orexigenic NPY may mediate binge eating episodes in our patient. This is supported by recent studies which demonstrated comparable NPY levels in normal-weight and obese subjects [28] while increased NPY concentrations were observed in patients with bulimia nervosa [29].

It was clearly demonstrated that subjects with $M C 4 R \mathrm{mu}-$ tations are able to lose weight under intensive lifestyle intervention $[4,5]$. However, long-term weight maintenance is difficult to achieve in these patients when only lifestyle modification is applied [5]. Therefore, other treatment strategies specifically addressing the uncontrolled hunger should be used. Efficacy of sibutramine to induce weight loss by decreasing the hunger score was shown in adolescents [30]. We assume that the reduction of hunger in our patient played a major role in the weight maintenance in response to the sibutramine treatment.

At this time, the patient is off any medication except for his long-term antihypertensive therapy. Hypertension is less frequently observed in $M C 4 R$ mutation carriers compared to non-carriers due to the reduced sympathoexcitability $[31,32]$. However, some hypertensive $M C 4 R$ mutation carriers, including homozygous carriers, have been identified [24, 27, 33]. In our patient, no increase in pulse rate and good control of hypertension by monotherapy with losartan during the sibutramine treatment could be explained by a low vasoconstric- 
tive muscle sympathetic nerve activity and reduced sympathoexcitability [31, 32].

In conclusion, sibutramine had a favourable effect on body weight maintenance and obesity-related health risks in this homozygous $M C 4 R$ mutation carrier. Our finding of hypogonadotropic hypogonadism in the homozygous $M C 4 R$ mutation carrier indicates that investigation of the hypothalamic-pituitary-gonadal axis should be considered in other $M C 4 R$ mutation carriers, especially in those with loss-offunction mutation.

\section{Acknowledgements}

We would like to express our sincere gratitude to Mark Huckabee for the language revision of our manuscript. The study was supported by the Czech research project of MSM VZ No. 0021620814.

\section{Disclosure Statement}

The authors declared no conflict of interest.

\section{References}

1 Clément K, Vaisse C, Lahlou N, Cabrol S, Pelloux V, Cassuto D, Gourmelen M, Dina C, Chambaz J, Lacorte JM, Basdevant $\mathrm{A}$, Bougnères $\mathrm{P}$, Lebouc Y, Froguel P, Guy-Grand B: A Mutation in the human leptin receptor gene causes obesity and pituitary dysfunction. Nature 1998;392:398-401.

$\checkmark 2$ Farooqi IS: Monogenic human obesity. Front Horm Res 2008;36:1-11.

3 Hebebrand J, Geller F, Dempfle A, HeinzelGutenbrunner M, Raab M, Gerber G, Wermter AK, Horro FF, Blundell J, Schafer H, Remschmidt $\mathrm{H}$, Herpetz S, Hinney A: Binge-eating episodes are not characteristic of carriers of melanocortin-4 receptor gene mutations. Mol Psychiatry 2004;9: 796-800.

4 Hainerová I, Larsen LH, Holst B, Finková M Hainer V, Lebl J, Hansen T, Pedersen O: Melanocortin 4 receptor mutations in obese Czech children: studies of prevalence, phenotype development, weight reduction response and functional analysis. $\mathrm{J}$ Clin Endocrinol Metab 2007;92:3689-3696.

$\checkmark 5$ Reinehr T, Hebebrand J, Friedel S, Toschke AM, Brumm H, Biebermann H, Hinney A: Lifestyle intervention in obese children with variations in the melanocortin 4 receptor gene. Obesity (Silver Spring) 2009;17:382-389.

6 Aslan IR, Ranadive SA, Ersoy BA, Rogers SJ, Lustig RH, Vaisse C: Bariatric surgery in a patient with complete MC4R deficiency. Int J Obes (Lond) 2011:35:457-461.

7 Aslan IR, Campos GM, Calton MA, Evans DS, Merriman RB, Vaisse C: Weight LOSS after Rouxen-Y gastric bypass in obese patients heterozygous for MC4R mutations. Obes Surg 2011;21:930-942.

$>8$ Danielsson P, Janson A, Norgren S, Marcus C: Impact sibutramine therapy in children with hypothalamic obesity or obesity with aggravating syndromes. J Clin Endocrinol Metab 2007;92:4101-4106.

9 Stunkard A, Messick S: The three-factor eating questionnaire to measure dietary restraint, disinhibition and hunger. J Psychosom Res 1985;29:71-83.

10 Devlin MJ, Goldfein JA, Dobrow I: What is this thing called BED? Current status on binge eating nosology. Int J Eat Disord 2003; 34(suppl 1):S2-S18.

11 Strobel A, Issad T, Camoin L, Ozata M, Strosberg AD: A leptin missense mutation associated with hypogonadism and morbid obesity. Nat Genet 1998;18:213-215.

12 Jackson RS, Creemers JWM, Ohagi S, RaffinSanson ML, Sanders L, Montague CT, Hutton JC, O'Rahilly S: Obesity and impaired prohormone processing associated with mutations in the human prohormone convertase 1 gene. Nat Genet 1997;16:303-306.
Mantzoros CS, Flier JS, Rogol AD: A longitudinal assessment of hormonal and physical alterations during normal puberty in boys. V. Rising leptin levels may signal the onset of puberty. J Clin Endocrinol Metab 1997;82:1066-1070.

14 Hadley M: Discovery that a melanocortin regulates sexual functions in male and female humans. Peptides 2005;26:1687-1689.

15 Van der Ploeg LH, Martin WJ, Howard AD, Nargund RP, Austin CP, Guan X, Drisko J, Cashen D, Sebhat I, Patchett AA, Figueroa DJ, DiLella AG, Connolly BM, Weinberg DH, Tan CP, Palyha OC, Pong SS, MacNeil T, Rosenblum C, Vongs A, Tang R, Yu H, Sailer AW, Fong TM, Huang C, Tota MR, Chang RS, Stearns R, Tamvakopoulos C, Christ G, Drazen DL, Spar BD, Nelson RJ, MacIntyre DE: A role for the melanocortin 4 receptor in sexual function. Proc Natl Acad Sci U S A 2002;99: 11381-11386.

16 Caquineau C, Leng G, Guan XM, Jiang M, Van der Ploeg L, Douglas AJ: Effects of $\alpha$-melanocytestimulating hormone on magnocellular neurones and their activation at intromission in male rats. $\mathrm{J}$ Neuroendocrinol 2006;18:685-691.

17 Backholer K, Bowden M, Gamber K, Bjørbaek C, Iqbal J, Clarke IJ: Melanocortins mimic the effects of leptin to restore reproductive function in lean hypogonadotropic ewes. Neuroendocrinology 2010;91:27-40.

18 Arver S, Lehtihet M: Current guidelines for the diagnosis of testosterone deficiency. Front Horm Res 2009;37:5-20.

19 Glass AR, Swerdloff RS, Bray GA, Dahms WT, Atkinson RL: Low serum testosterone and sexhormone-binding globulin in massively obese men. J Clin Endocrinol Metab 1977;45:1211-1219.

20 Zumoff B, Strain GW, Miller LK, Rosner W, Senie $\mathrm{R}$, Seres DS, Rosenfeld RS: Plasma free and nonsex-hormone-binding globulin-bound testosterone are decreased in obese men in proportion to their degree of obesity. J Clin Endocrinol Metab 1990;71:929-931.

21 Lima N, Cavaliere H, Knobel M, Halpern A, Medeiros-Neto G: Decreased androgen levels in massively obese men may be associated with impaired function of the gonadostat. Int J Obes 2000;24:1433-1437.

22 Hayes FJ, Seminara SB, Decruz S, Boepple PA, Crowley WF: Aromatase inhibition in the human male reveals a hypothalamic site of estrogen feedback. J Clin Endocrinol Metab 2000;85:3027-3035.

23 Vermeulen A, Kaufman JM, Deslijpere JP, Thomas G: Attenuated luteinizing hormone (LH) pulse amplitude but normal LH pulse frequency, and its relation to plasma androgens in hypogonadism of obese men. J Clin Endocrinol Metab 1993;76:1140-1146.
24 Farooqi IS, Yeo GS, Keogh JM, Aminian S, Jebb SA, Butler G, Cheetham T, O'Rahilly S: Dominant and recessive inheritance of morbid obesity associated with melanocortin 4 receptor deficiency. J Clin Invest 2000;106:271-279.

25 Kobayashi H, Ogawa Y, Shintani M, Ebihara K, Shimodahira M, Iwakura T, Hino M, Ishihara T, Ikekubo K, Kurahachi H, Nakao K: A novel homozygous missense mutation of melanocortin-4 receptor (MC4R) in a Japanese woman with severe obesity. Diabetes 2002;51:243-246.

26 Farooqi IS, Keogh JM, Yeo GS, Lank EJ, Cheetham T, O'Rahilly: Clinical spectrum of obesity and mutations in the melanocortin 4 receptor gene. N Engl J Med 2003;348:1085-1095.

27 Lubrano-Berthelier C, Dubern B, Lacorte JM, Picard F, Shapiro A, Zhang S, Bertrais S, Hercberg S, Basdevant A, Clement K, Vaisse C: Melanocortin 4 receptor mutations in a large cohort of severely obese adults: prevalence, functional classification, genotype-phenotype relationship, and lack of association with binge eating. J Clin Endocrinol Metab 2006;91:1811-1818.

28 Barth S, Klein P, Horbach T, Dotchs J, Rauh M, Rascher W, Knerr I: Expression of neuropeptide $\mathrm{Y}$, omentin, and visfatin in visceral and subcutaneous adipose tissues in humans: relation to endocrine and clinical parameters. Obes Facts 2010;3:245-251.

29 Sedlackova D, Kopeckova J, Papezova H, Vybiral S, Kvasnickova H, Hill M, Nedvidkova J: Changes of plasma obestatin, ghrelin and NPY in anorexia and bulimia nervosa patients before and after a high-carbohydrate breakfast. Physiol Res 2011;60: 165-173.

30 Berkowitz RI, Wadden TA, Tershakovec AM, Cronquist JL: Behavior therapy and sibutramine for the treatment of adolescent obesity: a randomized controlled trial. JAMA 2003;289:1805-1812.

31 Greenfield JR, Miller JW, Keogh JM, Henning E, Satterwhite JH, Cameron GS, Astruc B, Mayer JP Brage S, See TC, Lomas DJ, O'Rahilly S, Farooqi IS: Modulation of blood pressure by central melanocortinergic pathways. N Engl J Med 2009;360:44-52.

32 Sayk F, Heutling D, Dodt C, Iwen KA, Wellhoner JP, Scherag S, Hinney A, Hebebrand J, Lehnert $\mathrm{H}$ : Sympathetic function in human carriers of melanocrotin-4 receptor gene mutations. J Clin Endocrinol Metab 2010;95:1998-2002.

33 Mergen M, Mergen H, Ozata M, Oner R, Oner C: A novel melanocortin 4 receptor (MC4R) gene mutation associated with morbid obesity. J Clin Endocrinol Metab 2001;86:3448-3451. 